\title{
Science through English or English through science?
}

Shirley Carter-Thomas, Carl Storz and Gérard Carnat

\section{(2) OpenEdition}

\section{Journals}

Electronic version

URL: http://journals.openedition.org/asp/3774

DOI: 10.4000/asp.3774

ISSN: 2108-6354

\section{Publisher}

Groupe d'étude et de recherche en anglais de spécialité

\section{Printed version}

Date of publication: 1 December 1995

Number of pages: 175-184

ISSN: 1246-8185

\section{Electronic reference}

Shirley Carter-Thomas, Carl Storz and Gérard Carnat, « Science through English or English through science? », ASp [Online], 7-10 | 1995, Online since 24 September 2013, connection on 05 May 2019 URL : http://journals.openedition.org/asp/3774 ; DOI : 10.4000/asp.3774

This text was automatically generated on 5 May 2019.

Tous droits réservés 


\title{
Science through English or English through science?
}

\author{
Shirley Carter-Thomas, Carl Storz and Gérard Carnat
}

1 In this article we have set out to describe an integrated course ${ }^{1}$ that took place this year (1994-1995) at the Institut National des Télécommunications, Évry, France. This project involved collaboration between English teachers, a French scientific colleague and, of course, the students themselves. It is not only the team-teaching experience itself that we wish to focus on, but also some of the fundamental issues it raises with regard to the teaching of English for Specific Purposes today.

Before beginning to describe our experience, it is necessary to outline the academic setting we are working in and the general profile of the students involved.

\section{Institutional setting}

3 The Institut National des Télécommunications is one of the French Grandes Écoles specialising in telecommunications. On arrival most students will have studied English as a first language at Lycée and during their classes préparatoires (two-year intensive course work essentially in maths and science to prepare for a national competitive entrance exam into top engineering and business schools) and, in general, are already fairly proficient in English. There are, of course, exceptions at both ends of the scale but the average first-year student will be what we call a level " 2.5 " (on a scale of 1-4), that is to say someone who would pass the FCE exam with a good C or B grade.

Many of our students have also had the opportunity of spending a period of time in English-speaking countries, and although not fluent, they are able to maintain a general discussion on everyday topics. So far the picture we have painted is fairly rosy, but as is generally recognized, the jump from a good intermediate standard to that of advanced is very substantial, and making progress at this plateau level is often arduous. Furthermore, after up to 10 years of tuition in English, students can be rather cynical about the possibilities or even the usefulness of making further progress. 
In a professional environment, instrumental motivation is high - the benefits of increased fluency for the executive about to embark upon a series of meetings in the U.S.A., or the engineer who is about to present a paper at a conference are immediately obvious. In an academic setting, however, it is more difficult to motivate advanced learners. Although some do have extrinsic motivation, many cannot see any immediate benefit from investing their time in foreign languages, and all too often we have to resort to "stick and carrot" methods.

6 For motivation reasons, the English programme at the INT aims to offer a wide choice of theme courses to give students the opportunity of practising and improving their English through the study of a subject which interests them. The theme courses include, on the one hand, artistic subjects such as music, twentieth century literature, the cinema and on the other hand, more professionally oriented courses, such as negotiation skills, advertising, science and technology and telecommunications English. Last year, two specialised scientific courses in digital images and analogue television were proposed, for the first time. The latter dealt with the history and techniques involved in television broadcasting and included such topics as colorimetry, standards and digital techniques. The course on digital images, intrinsically more technical, dealt with the different procedures used to encode images and the various applications of these techniques.

\section{Practical organisation}

7 The impetus behind these two new courses was, however, not the language department but the head of engineering studies. For some time in fact, the language department had been under pressure from the directors of studies to further professionalise the content of the theme courses. This suggestion had met with resistance on the part of some language teachers who felt that perhaps their role was being called into question. In the case of scientific theme classes, the idea up until now had been "English through science". English was not the vehicle but the objective. In proposing a specialised scientific course, such as digital images, was not the content taking precedence over the language?

Collaboration between English teachers and other scientific staff in the language cursus was not new. Indeed for many years, members of the various scientific departments and English teachers have successfully collaborated on the supervision and correction of the scientific micro-project that all students have to produce in their third year. These projects still remain "English" projects and our role in teaching students the favoured 'stories', as Dudley-Evans (1993) calls them (see part 5) and structures related to the genre of academic report writing is clear. However, even after the initial shock (cf. Strevens in Robinson 1991: 79) of our participation in such a specialised course had faded, our role in the two new scientific courses was not as well defined.

Practically speaking the two new courses were organised in the following way. Each course (approximately 21 hours) was divided equally into two parts. The first was a series of lectures given in English by the director of studies on the two themes, that is analogue television and digital images, to all the students, which the language teachers were also asked to attend. The second consisted of concurrent language classes for smaller groups of around fifteen students, organised by the English teachers. At the end of the two courses the students had to submit an extended essay related to the subjects presented in 
the seminars, and present this report in a "conference" setting (in the lecture hall) to the science teacher, the English teachers, and interested fellow students.

\section{Content}

10 Now that we have generally situated the institution and practical organisation we will go on to look at the syllabus and framework of the course but first, and especially important in ESP, the needs must be determined. Whose needs? As previously mentioned, the head of engineering studies planned the course, which meant that the specific content or specific scientific genre (topic, terminology, text types, etc.), along with the overall goals and objectives and forms of assessment had already been decided upon. The student, it seemed, was required to develop the following skills:

- to follow a seminar or a long piece of oral discourse;

- to take notes;

- to ask pertinent questions;

- to answer questions;

- to research and write a paper;

- to communicate in the specialism.

11 As the structure of the course had been predetermined, and as the time available was limited, it was difficult to carry out a more complete target situation analysis. However, our experience in working with students of this level meant that we were able to make an intuitive present situation analysis. The human/affective factor should be taken into consideration in the needs analysis, bearing in mind that "ESP is teaching English to specified people", (Robinson 1991: 5) and that much of the learning process is a result of the relationship developed between learner and teacher (Nunan 1988: 4-5). Learners often find it difficult to formulate their needs or expectations themselves and may only realize what their needs are once the course has begun. We therefore have to be flexible and ready to sensitize learners to developing a critical insight into their needs (strengths and weaknesses). Because of all the constraints and variables (time, personalities, motivation, needs) it would seem essential for the syllabus to include:

- as wide a range of comprehensible input as possible;

- both written and oral contextualized practice activities;

- specific preparation exercises for the extended essay and oral presentation;

- an emphasis on "learning how to learn".

After the initial needs analysis stage, we gleaned material from a wide range of syllabuses to provide a variety of contextualized language content, exercises and tasks. In other words we opted for an eclectic approach. The courses covered the following areas (see Table 1).

Table 1. Areas covered by the courses

GENERAL LANGUAGE SKILLS 


\begin{tabular}{|c|c|}
\hline $\begin{array}{l}\text { SPEAKING } \\
\text { debriefing/summarising } \\
\text { formulating and handling questions } \\
\text { giving an oral presentation/using } \\
\text { one's voice }\end{array}$ & $\begin{array}{l}\text { READING } \\
\text { specialist's and learners' lecture notes } \\
\text { articles from an encyclopaedia, reference books, } \\
\text { professional journals } \\
\text { texts pertinent to final paper } \\
\text { proof-reading }\end{array}$ \\
\hline $\begin{array}{l}\text { PHONOLOGY } \\
\text { working on problem sounds and } \\
\text { word stress } \\
\text { pronouncing key words correctly } \\
\text { developing a system for dealing with } \\
\text { errors }\end{array}$ & $\begin{array}{l}\text { GRAMMAR }{ }^{2} \\
\text { articles } \\
\text { agreement } \\
\text { anaphora } \\
\text { collocations (N + PREP, } \mathrm{V}+\text { PREP, etc.) } \\
\text { comparatives } \\
\text { compound nouns } \\
\text { verb forms }\end{array}$ \\
\hline $\begin{array}{l}\text { LISTENING } \\
\text { listening to scientific/mathematical } \\
\text { lectures } \\
\text { listening for gist and detail }\end{array}$ & $\begin{array}{l}\text { LEXIS } \\
\text { technical vocabulary } \\
\text { collocations } \\
\text { word 'grammar' } \\
\text { metalexis (for an oral presentation) } \\
\text { "general lexis" (common core) }\end{array}$ \\
\hline $\begin{array}{l}\text { WRITING } \\
\text { note taking } \\
\text { spelling / punctuation } \\
\text { abstracts } \\
\text { translating } \\
\text { scientific project/report }\end{array}$ & \\
\hline $\begin{array}{l}\text { DISCOURSE } \\
\text { defining } \\
\text { history/evolution } \\
\text { comparing and contrasting } \\
\text { mathematical formulae } \\
\text { applications } \\
\text { problems }\end{array}$ & \\
\hline
\end{tabular}




\begin{tabular}{|c|c|}
\hline $\begin{array}{l}\text { FUNCTIONS AND NOTIONS } \\
\text { time and space } \\
\text { asking } \\
\text { seeking clarification } \\
\text { agreeing/disagreeing } \\
\text { defining } \\
\text { describing } \\
\text { exemplifying } \\
\text { explaining } \\
\text { justifying }\end{array}$ & \\
\hline $\begin{array}{l}\text { SKILLS } \\
\text { macro }\end{array}$ & $\begin{array}{l}\text { oral presentation } \\
\text { written paper }\end{array}$ \\
\hline micro & $\begin{array}{l}\text { speaking in front of an audience } \\
\text { body language } \\
\text { maintaining eye contact } \\
\text { using visuals } \\
\text { sign posting }\end{array}$ \\
\hline
\end{tabular}

13 This language syllabus or syllabuses reflects a very eclectic approach indeed, giving learners a wide variety of language exercises and learning experiences (Nunan 1988: 45). By being eclectic it is easier to cater for different learners' needs, levels, learning styles or expectations, and to deal with the scientific genre. (See Hutchinson \& Waters 1987: 37; Swan in Robinson 1992: 41)

14 After the planning stage, we looked for relevant, existing course materials but few suited the specific context. We tried not to reinvent the wheel, but it was necessary to make up a few contextualized grammar (e.g., use of the article), lexical and phonological exercises using different texts: encyclopaedia entries, newspapers, scientific journals and even former learners' papers. Texts were not only used as a source for discrete linguistic item work, but also for general reading and writing skills in connection with the end-of-term essay. TV science documentaries and radio technology reports also provided us with a good opportunity to practice a variety of skills.

We were also able to draw on work submitted by former students to make up exercises, especially to encourage proof reading, accuracy, and good writing. Our scientific colleague not only provided the scientific input, but his linguistic errors sometimes provided us with an opportunity to work on phonetics and certain structural features which often raise problems for learners at this level.

16 The practice activities proposed usually went beyond the sentence level, considering large chunks of language, and setting discrete language items in context. Activities focused on the four skills, grammar, lexis and phonology, culminating in the preparation of the final written paper and oral presentation. 


\section{Evaluation of the courses}

17 From the English teacher's point of view the two new courses, although encouraging us to develop a wealth of new ideas and teaching material, left us with some serious reservations. We felt that the science teacher was in an awkward position, being judged by a very critical public not only on his performance as a science lecturer, but on his performance as a non-native speaker of English. As English teachers, we also felt embarrassed at times at being placed in the position of pseudo-scientists. Was it not a language class after all? What were the objectives? What was our role? This confusion, perhaps for the most part due to a lack of clarity, preparation and organisation, was something that also disturbed the students.

Students in their written anonymous evaluations of the two courses naturally picked up on some of the same questions:

- What are the objectives of the course?

- Why was there such emphasis on the content and why was this content so technical?

- What is the role of the scientific instructor? Why use a non-native speaker?

It is true that many students were unhappy about being exposed to "non-native" English, but retrospectively, on the other hand, it is justifiable in that they will very likely meet many varieties of English in their professional careers.

Students appreciated the fact that the two subjects were taught concurrently, and that they were learning language presented complete with its context. They also welcomed the opportunity of attending a lecture, taking notes, and making their final oral presentation.

21 Surprisingly, however, there were very few comments on the performance of the language teachers, except as regards our role in the scientific lectures. Although we were present to improve our knowledge of the subject matter and genre, the learners felt we should carry out our role as linguistic experts; interrupting the lecture when necessary to correct linguistic errors or answer questions concerning the English spoken by the French scientific instructor.

\section{Theoretical issues}

Reflections on some of the fundamental issues we encountered teaching an integrated course Beyond ESP?

22 As far as our two technology courses are concerned, the ESP concept largely determines and even restricts the scope of objectives, task types and language to be presented. It is an academic experience, a first exposure to the genre and an encouragement for students to "learn how to learn", providing them with the necessary skills which should help them to deal with their subject matter in English in a professional context.

What is the role of the various participants in an integrated course?

Let us begin by asking another question. As there was a certain confusion as to teachers' roles, would the simplest solution not be to find an English teacher, with a higher degree in engineering, or else a bilingual telecommunications engineer who is also a linguist? In 
other words, wouldn't it be better to have an all-round specialist? Even if such people were easy to find, we do not believe this would be the solution. Concentrating "all the knowledge" in the hands of one individual would not seem to be the most appropriate way to encourage students, particularly at this delicate higher intermediate level, to take the responsibility for their own linguistic progress, whether it is through the study of a specific scientific subject or any other field of interest. As explained in an article in Philip Riley's compilation Discourse and learning (Riley 1985):

The fact that it is the teacher who knows and controls every thing may be very reassuring for both him and his learners, but will also militate against the learners ever achieving any degree of autonomy in the matter.

In an integrated course, the science specialist's participation is necessary to supply a large part of the technical content. The language teacher's role is to provide students with the means to master the genre in question, that is to say the type of discourse typical of their specialisation. It is important for the teacher to : become familiar with ESP course materials, shape the input, encourage learners to learn (especially from their errors), manage learning strategies, promote language practice and use (Strevens in Robinson 1991 :80), and give appropriate feedback. The idea, however, is not to spoonfeed students with the "right answers" in a foreign language.

While as English teachers in an engineering school we felt it was our role to interest ourselves in the subjects our students were studying, this does not extend to complete mastery of the subject, so as to be able to replace a scientific specialist. As T. DudleyEvans points out (1993):

Clearly one needs an interest in the discipline and a willingness to find out about the genre conventions and the favoured 'stories', but one does not necessarily need to have detailed knowledge of the actual content. One needs to try to find out how the discipline works, what sort of questions they are seeking answers to, rather than necessarily know or understand all the answers.

26 As far as the learners' role is concerned, it would seem obvious that they have a very active part to play in determining course content and developing reusable language skills, going beyond the rather restricted world they have known in the past to responsibly, autonomously and professionally opening up to new experiences. Rather than relying on the teachers to provide both the linguistic analyses and specialist knowledge, could we not further exploit the students' knowledge of their scientific specialties. We believe that learners as budding specialists can teach other learners, and thus play an essential role in obtaining the added accuracy and fluency they require to become more autonomous. In such a way too we could encourage "action research" (Kennedy in Nunan 1988: 83). In short we would thus foster greater autonomy and responsibility, and significantly change the roles both of teacher and student.

\section{Are we teaching science or English?}

We are teaching a mixture of the two. The objectives have to be clear and the roles well defined from the beginning. Language teachers can acquire the basic "stories", encourage learning, present skills, techniques, correct language errors, etc. The balance between language content and science content is variable; some activities focus on content while others focus on language in context. Any variation of weighting is possible, but the language skills/techniques introduced by the language teacher are just as indispensable as those contributed by the scientific expert. Language does not exist for language's sake. There is little reason not to link subject content and language learning as neither exists 
independently, and most course materials do have some kind of theme base, whether it be cultural, business, or scientific.

\section{Future perspectives and conclusion}

The first point is obviously to build on what we have already started to create. (Nunan 1988: 55) As part of the planning stage to better analyse needs and establish and negotiate objectives, we need to help our learners become familiar with what it means to learn a language, and how to come up with a clear contract of goals and objectives. We must plan in advance in closer collaboration with all participants, and exchange information, material, etc. In so far as actual implementation is concerned we must further define the subject and find more appropriate texts (both oral and written). However, this does not mean creating a package course as no two courses or groups will ever be the same.

To encourage more "action" research by exploiting former learners' and teachers' materials, we are going to organise a seminar on the creation of a digital image database using some of the material created after testing and rewriting it. As many of our learners are engineers who are also studying data processing, the idea is to involve them even more in a real world professional experience in which they have to communicate in English, learn how to develop and apply their knowledge of computer programming, learn how to use new software, etc. Macro-skills (working in a team, solving problems, creating a new, useful, reusable product, etc.) would also come into the picture.

Another idea is to create a "course" which would deal with giving scientific papers, in other words simulate a scientific congress on "digital images" or another topic. We would establish a corpus of different types of papers (informative, comparative, persuasive) to present to a group. Learners would have to do research, write and present papers, in other words they would become "scientific experts". Language and content would be authentically linked.

In conclusion, the role of language teachers in planning and implementing a contextualized (professional, scientific) learning situation of the type we have described, although requiring a substantial investment was, in our case, extremely rewarding. It is true that managing the specific genre, negotiating a number of syllabuses in class while also trying to encourage learners to become more autonomous and linguistically accurate can be a daunting process. It was, however, a motivating, and in the words of Strevens (in Robinson 1991: 79), "shocking" learning experience for all participants. The shock can be put down both to the highly technical nature of the subject, and also to the fact that it was a challenging new experience for all concerned.

\section{BIBLIOGRAPHY}

Dudley-Evans, T. 1993. "Subject specificity in ESP: How much does the teacher need to know?". ASp 1, 1-9. 
Hutchinson, T. and A. Waters. 1987. English for Specific Purposes. Cambridge: Cambridge University Press.

Nunan, D. 1988. The Learner Centred Curriculum. Cambridge: Cambridge University Press.

Riley, P. 1985. Discourse and Learning. London: Longman.

Robinson, P. 1991. ESP Today. Hemel Hempstead: Prentice Hall.

\section{NOTES}

1. Other related terms include: co-operative teaching, team-teaching, peer teaching, and language across curriculum (LAC).

2. Scientific expression calls for a high degree of precision and thus of linguistic accuracy. Learners do not often realise the need or importance, even after ten years of language training, of being accurate (grammar, lexis and phonology) for various reasons: 1. they may think they are able to communicate reasonably well with native English speakers especially after having spent time in an English speaking country as a learner or a job trainee; 2. they may be focusing on content (message) and not on form; 3 . they are sometimes simply careless.

\section{ABSTRACTS}

It is often difficult to motivate advanced learners, particularly in an academic setting rather than a practical working environment. We report on new specialised scientific courses dealing with analogue television and digital images. Many issues are raised, covering not only the much debated question about the extent to which the ESP teacher should be acquainted with the scientific discipline of his/her students, but also that of learning from specialists whose command of English is not perfect. Perhaps the most important issue raised however is whether the students are learning English through science or science through English.

Il n'est pas facile de motiver les apprenants de bon niveau, surtout dans l'environnement d'une École plus que dans le milieu du travail. Cet article rend compte de deux nouveaux cours d'anglais scientifique se rapportant à la télévision analogique et aux images numérisées. De nombreux points sont traités, non seulement la question très discutée de savoir quelle connaissance de la discipline scientifique de ses étudiants le professeur d'anglais de spécialité doit avoir, mais aussi celle de ce qu'on peut apprendre de spécialistes dont la maitrise de l'anglais est imparfaite. Cependant, la question la plus importante demeure celle de savoir si les étudiants apprennent l'anglais grâce à la science, ou l'inverse.

\section{INDEX}

Mots-clés: anglais scientifique, apprentissage, télécommunications

Keywords: learning, scientific English, telecommunications 


\section{AUTHORS}

\section{SHIRLEY CARTER-THOMAS}

Shirley Carter-Thomas teaches at Institut National des Télécommunications, Évry, France. Shirley.Thomas@it-sudparis.eu

\section{CARL STORZ}

Carl Storz teaches at Institut National des Télécommunications, Évry, France. carl.storz@itsudparis.eu

\section{GÉRARD CARNAT}

Gérard Carnat teaches at Institut National des Télécommunications, Évry, France. 